cal sciences, of which 195 million and 197 million dollars, respectively, were in the universities and colleges; for industry the corresponding figures were 27 million and 245 million dollars, respectively; for other non-profit institutions, 27 million and 33 million dollars ; and for Federal Government institutions, 33 million and 78 million dollars. For 1953-54, the corresponding figures are: colleges and universities, 92 million and 116 million dollars ; industry, 9 million and 142 million dollars ; other non-profit institutions, 14 million and 12 million dollars; and for Federal Government institutions, 17 million and 30 million dollars.

\section{The Indian Potato Journal}

The Indian Potato Journal, issued by the Indian Council of Agricultural Research (1; April 1959. Ed., P. L. Jaiswal. New Delhi. Rs. 6.00 per annum) as a half-yearly periodical, will be devoted exclusively to the improved cultivation of this crop. The journal contains original scientific papers, general articles and reviews of relevant research. Thus, in Vol. 1, No. 2, there are contributions on such topics as the effect of nitrogen fertilizers on the yield and chemical composition of potatoes ; the crossability of diploid Solanum species; growth and tuber formation; control of sprouting by growth regulators; Kashmir as a potential seed potato area.

\section{Geodesy and Artificial Satellites}

IN a recent issue of Smithsonian Contributions to Astrophysics (3, No. 9. Pp. iv +95-161. (Washington, D.C. : Government Printing Office, 1960.) 65 cents), entitled "Geodetic Uses of Artificial Satellites", G. Veis gives a detailed mathematical exposition of methods for extracting geodetic information from observations of artificial satellites. Most of the geodetic results so far obtained from satellites have stemmed from their orbital perturbations; this paper lays the foundation for the satellites' other role, when they act as aerial triangulation points and can be utilized directly, without the intervention of dynamical theory. A second recent publication on this topic is "Use of Near-Earth Satellite Orbits for Geodetic Information", by P. D. Thomas (Technical Bulletin No. 11 of U.S. Coast and Geodetic Survey. Pp. ii +36 . (Washington, D.C. : Government Print. ing Office, 1960.) 45 cents). This is a lively and rather informal review of results up to the end of 1959 on the Earth's flattening, which satellites have shown to be $1 / 298 \cdot 2$ rather than $1 / 297$, as previously believed. The paper also discusses the methods of observing satellites and some related topies.

\section{Fluctuations in the Level of the Caspian Sea}

Tre level of the Caspian Sea (Nature, 179, 1112 ; 1957), after many years of fall, in 1957 began to rise in spite of a marked decrease in the inflow of the river water. According to B. G. Richter (Priroda, 2, $45 ; 1960$ ), this rise can be explained by the nature of the tectonic movements occurring in this region, and which tend to alter the volume of the hollow in which the Caspian Sea is situated. A map showing areas of elevation and areas of sinking explains the relative rapid rise of the land in the region of Baku and in parts of the eastern shore of the Caspian Sea, especially the rapid drying up of the salt-producing bay of Kara-Boghaz-Gol (Nature, 179, 409; 1957), which is discussed by V. D. Polyakov (Priroda, 3, $93 ; 1960$ ).

\section{Protease Inhibitor in Human Blood}

SERUM trypsin and chymotrypsin inhibitors have been determined with reasonable accuracy by a modified ultra-violet absorption method. The serum examined was diluted thirty times with normal saline. N. Aizawa reports in the April issue of the Yokohama Medical Bulletin that both inhibitors were found to be stable below $3^{\circ} \mathrm{C}$. for about fifty days, and that 20 per cent of trypsin inhibitory activity was maintained even after heating at $60^{\circ} \mathrm{C}$. for $30 \mathrm{~min}$. On the other hand, inhibitory activity against chymotrypsin completely disappeared under the same conditions. It seems difficult to conclude that both inhibitory activities are exerted by a single inhibitor. Further experiments showed that the trypsin inhibitory principle was found to pass gradually through a 'Cellophane' membrane; it is probable that the inhibitory factor is a relatively lower molecular substance than hitherto supposed. From the fact that trypsin inhibitory activity was recovered by neutralization, even after the incubation of the serum for $24 \mathrm{hr}$. at less than $p \mathrm{H} 5 \cdot 0$, the $p \mathrm{H}$ inactivation may be a reversible change.

\section{The Stone Age in Jersey: Saint Brelade's Cave}

SaInt Brelade's Cave in Jersey, British Channel Islands, has long been known as an important prehistoric site of the Stone Age. Following some preliminary digging it was partially excavated by the late Dr. R. R. Marett in 1913, but the First World War stopped the work, and though it was continued later, the bottom layers were never reached. An important Mousterian industry was, however, unearthed. Recently, Father Christian Burdo has re-examined the site, and excavated the lower layers where he has found an Acheulean assemblage. Dr. Zeuner dates the cave infilling to a period from the end of the Riss glaciation to the start of the Würm. The Société Jersiaise has published an excellent account of the finds which can be obtained from the Museum, 9 Pier Road, Jersey (Excavation of a PreMousterian Horizon, 1950-1958. Pp. $77+8$ plates. (Jersey, Ch. Is. : Société Jersiaise. 7s.)). Several of the implements are illustrated, and a list of the fauna and flora found given. There are also some excellent full-page photographs of the site itself.

\section{James Picker Foundation:}

Radiological Research Awards

ON behalf of the James Picker Foundation, the National Academy of Sciences-National Research Council is accepting applications for fellowships and grants in the field of radiology and nuclear medicine for the year 1961-62. The awards are made in four categories : Advanced Fellowships in Academic Radio$\log y$, offered for the first time during the past year, the purpose of which is to prepare the candidate who has completed his or her clinical training in radiology to meet in full the intellectual demands of an academic position in radiology; Postdoctoral Fellowships in Radiological Research are open to recent graduates who desire experience and training in scientific investigation, and while these awards are for a period of one year, requests for renewal will be considered; Grants for Scholars are a transitional form of support, designed to bridge the gap between the completion of research fellowship training and the period when the young scientist has thoroughly demonstrated his competence as an independent 